\title{
A New Polynucleotide-Polysaccharide Complex and its Application to Functional Oligonucleotide Delivery
}

\author{
多糖、核酸による複合体形成と機能性核酸デリバリーへの応用
}

\begin{abstract}
Anada, Takahisa ${ }^{\text {a }}$, Sakurai, Kazuo ${ }^{\text {a }}$; and Shinkai, Seiji ${ }^{b}$
${ }^{a}$ Department of Chemical Process \& Environments, The University of Kitakyushu, 1-1, Hibikino, Wakamatu-ku, Kitakyushu, Fukuoka 808-0135, Japan, fax: +81-93-695-3390, 'Faculty of Engineering, Department of Chemistry \& Biochemistry, Graduate School of Engineering, Kyushu university, 6-10-1 Hakozaki, Higashi-ku, Fukuoka 812-8581 Japan

FAX: 81-92-642-3611, E-mali: seijitcm@ mbox.nc.kyushu-u.ac.jp
\end{abstract}

Key Words: Schizophyllan, $\beta$-(1-3)- Glucan, Renaturation, Complexation, Oligonucleotide

\begin{abstract}
Schizophyllan (SPG) is a polysaccharide that belongs to the $\beta-(1-3)$ glucan family and adopts a triple-helixical conformation in water. When SPG dissolves in dimethyl sulfoxide (DMSO), the triple helix is dissociated to three random coils. When water is added to the DMSO solution (renaturation), the single chain of SPG (s-SPG) collapses owing to both hydrophobic interaction and hydrogen bonding formation, and eventually aggregation takes place with increasing the water content. When this renaturation process is carried out in a mixture containing s-SPG and a single-stranded polynucleotide, a macromolecular complex is formed, consisting of two s-SPG chains and one polynucleotide chain. This novel complexation was examined with circular dichroism, UV spectroscopy, and gel electrophoresis. We applied to this complex to deliver functional oligonucleotides such as antisense DNA and $\mathrm{CpG}$ motifs. The biological functions of these oligonucleotides were extremely enhanced owing to the complexation.
\end{abstract}

要 約

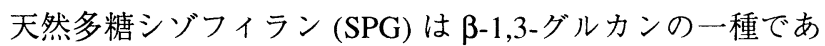
り、水中で三本鎖状態をとっているがジメチルスルホキシド (DMSO) に溶解させると、三本鎖がほどけて一本鎖ランダムコ イル状態となる。この DMSO 溶液を水に置換すると、SPG一本 鎖が疎水性相互作用と水素結合形成により折りたたまれ再び三 本鎖状態へと戻る (再生)。我々はこの再生過程に一本鎖核酸が 共存すると二本の SPG 鎖と一本の核酸鎖からなる高分子複合体 を形成することを見出した。この多糖/核酸複合体形成を円偏光 二色性、UVスペクトル及びゲル電気泳動により確認した。さら に、SPG 複合体形成を利用してアンチセンス DNA や CpG DNA などの機能性核酸の細胞内デリバリーを行い、これら機能性核 酸の活性が複合化によって大幅に増強されることを見出した。

\section{A. Introduction}

Polysaccharides are abundant natural sources which can offer a wide variety of useful products to human beings. Most of them are used as bulk chemicals, such as coating, gelling, and binding agents, food additives. Recently, gene delivery has attracted attention as a fine chemical application of polysaccharides. This is because polysaccharides are normally biodegradable and give less stress to biological systems when they are used as the delivery material. Currently, viral vectors are most commonly used for gene delivery because of their high transfection efficiency. However, they all induce an immunological response to some extent and have been pointed out as a safety issue that is ascribed to insertional mutagenesis $(1,2)$. On the other hand, non-viral-based gene delivery systems have a great advantage because of the absence of infectious or mutagenic capability. Therefore, the future of gene therapy depends on the emergance of good non-viral vectors, although most of them
A. はじめに

多糖は人々の生活の中でコーティング剂、ゲル化剂、食品 添加凨などとして広く有効利用されている天然資源である。ま た、多糖は生分解性で、生体へのストレスを与えないことか ら、近年、遺伝子導入に利用されファインケミカルとしての応 用が注目されている。現在、遺伝子治療に扔いてウイルスベク ターはその効率の良さから広く用いられている。しかしなが ら、免疫反応の惹起や、ランダムな染色体組込みによる発ガン の問題など安全性に問題が残されている $(1 、 2)$ 。一方、非ウイル 不性ベクターは病原性、変異原性のないことが利点となってお り、将来の遺伝子治療を担うべクターとして期待されているが 依然発展途上の段階である (3)。実際に非ウイルス性ベクターに は多くの解決すべき問題点が残されており、特にトランスフェ クション効率の低さは大きな欠点である。ポリエチレンイミン 
are still under development (3). In fact, non-viral vectors have many problems to be overcome; among others, its poor transfection is a serious drawback. Synthetic polycations, such as polyethyleneimine $(4,5)$, poly(L-lysine) (6), and cationic lipid (7-9) have been studied as a gene or oligodeoxynucleotide (ODN) carrier. However, one drawback of these cationic polymers and lipids is its inherent cytotoxicity.

Schizophyllan (SPG) is an extracellular $\beta$-(1-3)-D-glucan, having one $\alpha$-6-1-linked glucose residue as the side chain, produced by the fungus Schizophyllum commune $(10,11)$. Chemical structure of SPG is shown in Fig. 1. Norisuye et al. $(12,13)$ extensively studied dilute solution properties of SPG and found that it dissolves in water as a triple helix. The triple helix is stabilized by intermolecular hydrogen bonds among the three glucan chains. The triple helix is destroyed by dissolving it in dimethylsulfoxide (DMSO) to yield three single chains (s-SPG). When water is added to the DMSO solution (renaturation), the triple helical structure can be partially retrieved through this process. Recently, Sakurai and Shinkai demonstrated that s-SPG forms a macromolecular complex with some polynucleotides, when those polynucleotides are present during the renaturation process (14). It is known that SPG is a non-toxic polymer, and has been used as an antitumor medicine for clinical cure for almost 20 years in Japan. The present review summarizes some characteristic features of this novel polysaccharide-polynucleotide complex and application to DNA carrier for antisense and immunostimulant oligonucleotides.

\section{B. Polysaccharide/Polynucleotide Complex}

\section{B-1. Spectroscopic Changes upon Complexation (14-16)}

Figure 2 compares the circular dichroic (CD) spectra between the polynucleotides and their mixtures with s-SPG at 5 ${ }^{\circ} \mathrm{C}$, where $[\theta]$ is the molecular ellipticity. For the mixture of poly(A) and s-SPG (poly(A) + s-SPG), addition of s-SPG increases the $\mathrm{CD}$ intensity at around $260 \mathrm{~nm}$ by more than double, for poly $(C)+s-S P G$, the addition increases the peak at $275 \mathrm{~nm}$ by about 1.5 times and generates a new peak around $245 \mathrm{~nm}$. Since s-SPG itself has no absorption in the $230-320 \mathrm{~nm}$ region, the change in $\mathrm{CD}$ can be ascribed to conformational changes of the polynucleotides. Furthermore, it is interesting that difference in the base molecule shows the distinctive difference in the $\mathrm{CD}$ spectral changes. Based on these facts, we conclude that the
(4、5)、ポリ (L-リジン) (6) などの合成カチオン性高分子やカチ オン性脂質 (7-9) が非ウイルス性遺伝子、オリゴヌクレオチド $(\mathrm{ODN})$ キャリヤーとして研究されているが、これらのカチオン 性導入片は細胞毒性が高いことが問題点となっている。

シゾフィラン (SPG) は Schizophyllum commune 菌から産生

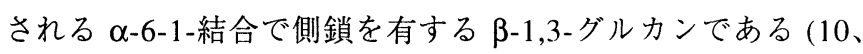
11)。SPG の化学構造を図 1 に示す。Norisuye ら (12、13) はSPG 希釈溶液について広く研究を行い、水中で三本鎖らせん構造を とって溶解していることを確かめた。この三重らせんは三本の グルカン鎖間の分子間水素結合により安定化されているが、 DMSO 中ではらせんが解け、一本鎖 (s-SPG) となる。DMSO 溶 液に水を添加していくと三重らせん構造が部分的に復元する(再 生)。最近、Sakurai と Shinkai はこの再生過程に一本鎖核酸が共 存すると一本鎖 SPG と核酸が高分子複合体を形成することを発 見した (14)。SPG は毒性がなく日本で 20 年にもわたり抗腫瘍 薬として臨床で用いられていることから安全性が保証されてい る高分子である。そこで我々は多糖/核酸複合体をアンチセンス 療法や免疫賦活治療のための DNAキャリヤーへの応用をおこ なっている。本報ではこの多糖/核酸複合体の性質とDNA デリ バリーにおける我々の最近の研究成果について述べる。

\section{B. 多糖/核酸複合体}

\section{B-1. 複合体形成に伴うスペクトル変化 (14-16)}

図 2 に $5^{\circ} \mathrm{C}$ における核酸と s-SPG 混合溶液の円二色性偏光 (CD) スペクトルを示す。 $[\theta]$ はモル楕円率を示す。poly (A) と s-SPG 混合溶液 (poly(A) + s-SPG) では、s-SPG 添加によって 260 $\mathrm{nm}$ 付近の $\mathrm{CD}$ 強度が 2 倍以上に増加した。 $\operatorname{poly}(\mathrm{C})+\mathrm{s}-\mathrm{SPG} に$ おいては $275 \mathrm{~nm}$ のピークが約 1.5 倍増加し、 $245 \mathrm{~nm}$ 付近に新 たなピークが出現した。s-SPG 自体には 230～320 nm 領域に吸 収がないことから CD 変化は核酸構造の変化に伴うものであ る。また、核酸塩基の違いにより異なる CD スペクトル変化を 示すことは興味深い結果である。前述の結果をまとめると、CD

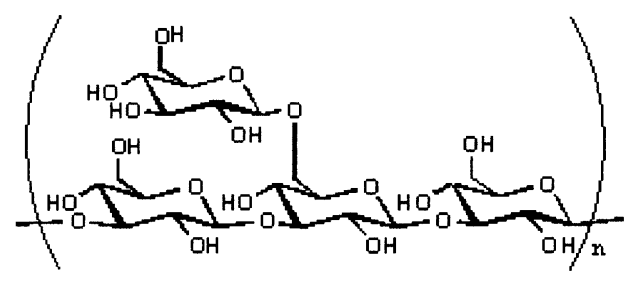

Fig. 1. Chemical structure of schizophyllan. 


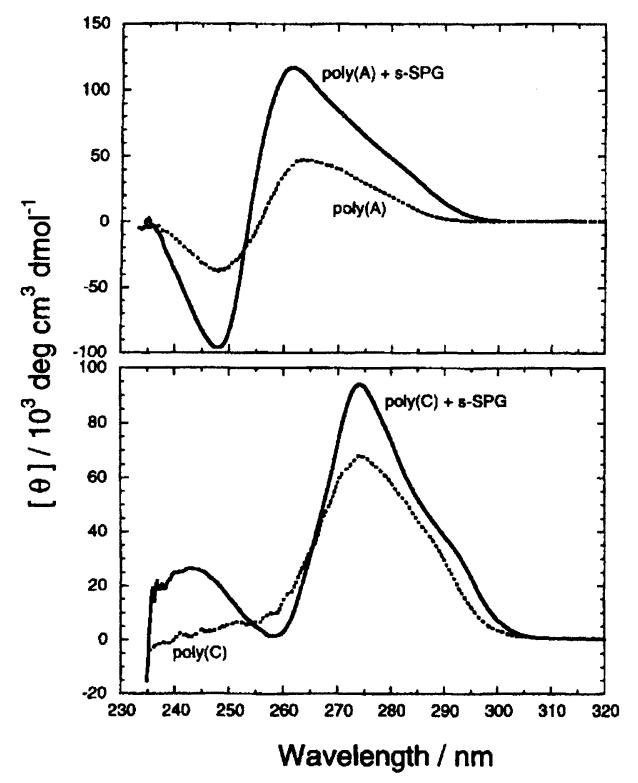

Fig. 2. Comparison of the CD spectra at $5^{\circ} \mathrm{C}$ between the single-stranded polynucleotides and their mixtures with s-SPG. $\mathrm{V}_{\mathrm{w}}=0.92, \mathrm{C}_{\mathrm{poly}(\mathrm{X})}=0.007-0.008 \mathrm{~g} /$ $\mathrm{dL}$, and $\mathrm{C}_{\mathrm{s}-\mathrm{SPG}}=0.06-0.07 \mathrm{~g} / \mathrm{dL}$. The dotted and solid lines indicate the CD spectra for the polynucleotides and their mixtures with s-SPG, respectively. Here $\mathrm{V}_{\mathrm{w}}$ means the water volume fraction of $\mathrm{DMSO} /$ water mixtures.

$\mathrm{CD}$ spectral changes can be ascribed to a specific interaction between the glucose unit of s-SPG and the nucleic base unit of the polynucleotides, is not ascribed to "ionic" hydrogen bonding with the phosphate unit. Fig. 3 compares the temperature dependence of $[\theta]_{\max }$ between polynucleotides and their complexes, where $[\theta]_{\max }$ is the $\mathrm{CD}$ intensity as the top of the positive band. As seen in the figure, there is an abrupt decrease in $[\theta]_{\max }$ around 32 and $54{ }^{\circ} \mathrm{C}$ for poly(A)/s-SPG and poly(C)/s-SPG, respectively. Furthermore, above each critical temperature, the mixture's $[\theta]_{\max }$ merges in the same values of the corresponding polynucleotide itself. These features show that s-SPG/polynucleotide complexes are formed only at lower temperatures and they dissociate upon heating. The abrupt decrease is associated with autoaccelerative dissociation of the complexes. It is interesting that this abrupt decrease is similar to the well-known melting behavior of double helix DNAs.

\section{B-2. Base Molecule Specificity $(16,17)$}

We demonstrated that SPG shows nucleotide specificity in the complex formation. None of $\operatorname{poly}(\mathrm{G}), \operatorname{poly}(\mathrm{U})$, poly(I), poly $(\mathrm{dG})$, and poly $(\mathrm{dC})$ shows complexation in neutral and nonsalt aqueous solution. However, the addition of alkaline cations induce complexation between poly(U) and s-SPG. The complex stability strongly depends on both the cation species and the salt concentration. Among others, potassium can induce the complexation most sensitively. Therefore, we can control the complexation in an on-off manner by changing the $\mathrm{KCl}$ concen-

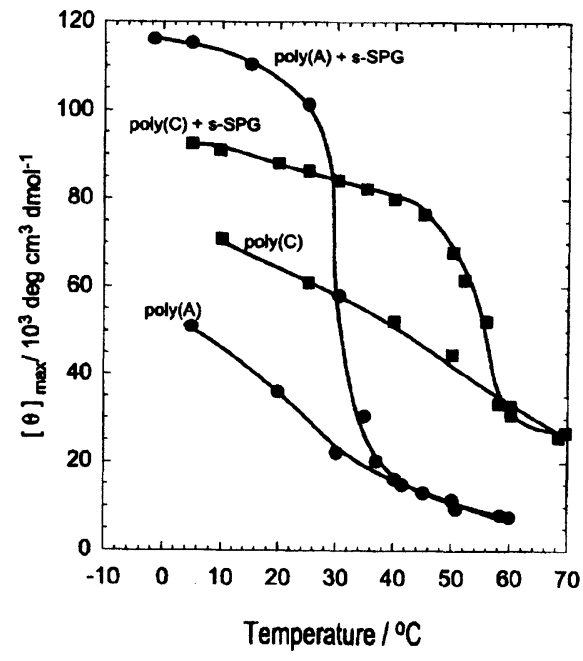

Fig. 3. Temperature dependence of $[\theta]_{\max }$ for the polynucleotides and their mixtures with s-SPG.

スペクトル変化は核酸リン酸基とのイオン性結合によるもので はなく、s-SPG のグルコースユニットと核酸塩基間の特異的相 互作用によるものであることが示唆される。図 3 は核酸とその 複合体における正のモル棈円率極大值 $\left([\theta]_{\max }\right)$ の温度依存性であ る。 $\operatorname{poly}(\mathrm{A}) / \mathrm{s}-\mathrm{SPG}$ 複合体、 $\operatorname{poly}(\mathrm{C}) / \mathrm{s}-\mathrm{SPG}$ 複合体はそれぞれ32 ${ }^{\circ} \mathrm{C} 、 54^{\circ} \mathrm{C}$ 付近で急激な $[\theta]_{\text {max }}$ の減少が見られ、臨界温度以上で は $[\theta]_{\max }$ がそれぞれの核酸のみの場合とほぼ同じ值となった。 これらの特徵は s-SPG/核酸複合体は低温域のみで形成され、加 熱によって解離することを示している。つまり、 $[\theta]_{\max }$ の急激な 減少は協同的な複合体解離現象に伴うものであり、このような $[\theta]_{\max }$ 変化はよく知られている二本鎖核酸の融解に伴うものと同 一の現象である。

\section{B-2. 核酸塩基特異性}

SPG 複合体形成はすべての核酸で起こるものではなく、塩 基特異性が見られる。 $\operatorname{poly}(\mathrm{G}) 、 \operatorname{poly}(\mathrm{U}) 、 \operatorname{poly}(\mathrm{I}) 、 \operatorname{poly}(\mathrm{dG})$ 及び $\operatorname{poly}(\mathrm{dC})$ は中性、無塩水溶液中で複合体を形成しない。しかし ながら、poly(U) の場合にはアルカリ金属イオンの添加によって s-SPG と複合体を形成することがわかった。この複合体の安定 性は金属イオンの種類と塩濃度に強く依存し、カリウムイオン 濃度に最も敏感である。つまり、 $\mathrm{KCl}$ 濃度を変化させることで 


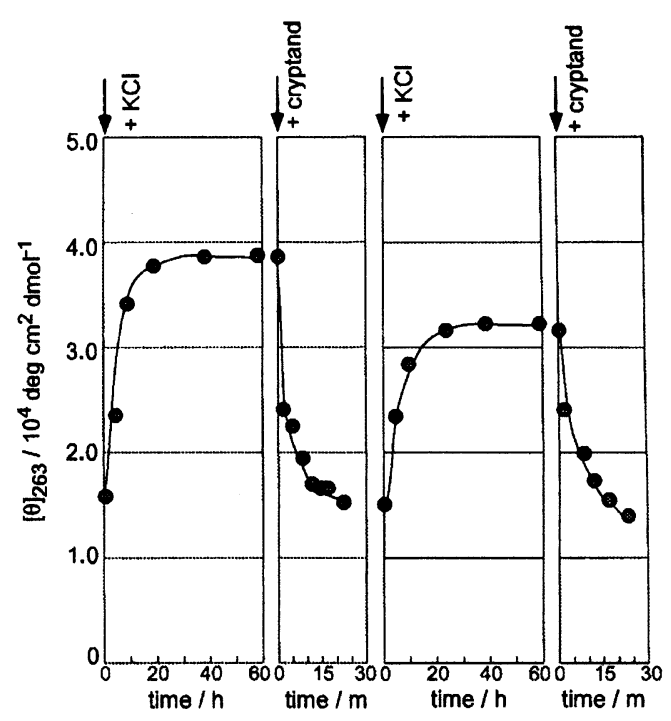

Fig. 4. Switching the complexation by adding $\mathrm{KCl}$ and cryptand alternatively. The poly(U) and s-SPG molar concentrations were $2.6 \times 10^{-4}$ and $6.4 \times 10^{-4} \mathrm{M}$, respectively.

tration. Since cryptand $[2,2,2]$ is a well known strong ligand for potassium, we can control the free potassium cation concentration in the system by adding cryptand. Fig. 4 demonstrates that the complexation is almost reversibly switched on and off by alternatively adding $\mathrm{KCl}$ and cryptand.

We found that poly $(\mathrm{C})$, poly $(\mathrm{A})$, poly $(\mathrm{dA})$, and $\operatorname{poly}(\mathrm{dT})$ can form a complex with s-SPG. According to the previous work (18), poly(G), poly(dG), poly(U), poly(dC), and poly(I) form inter- or intra- molecular interactions, thus the hydrogenbonding sites in the bases are already used. In contrast, $\operatorname{poly}(\mathrm{C})$, poly(A), poly(dA), and poly(dT) do not form such an intramolecular aggregation, therefore, their hydrogen-bonding sites are unoccupied. This correspondence evidences that the hydrogenbonding interactions are essential to induce the interaction between polynucleotide and s-SPG.

\section{B-3. Properties of Polynucleotide/SPG Complex}

$<$ Stoichiometry (16) $>$ We determined the stoichiometry for the poly(A), poly(dA), and poly(C) complexes. The results indicate that the complexation is undergone in a highly stoichiometrical manner and the stoichiometric number suggests that two main-chain glucoses and one nucleotide base are bound with each other, in other words, two s-SPG chains and one polynucleotide chain form a triple helix.

$<$ Nuclease resistance (19) $>$ The polynucleotides bound in the complex are more stable against the nuclease-mediated hydrolysis than the naked polynucleotides. The kinetic study of the enzyme reaction showed that the simple Michaelis-Menten relation is held and the maximum velocity for the complex is one-sixth as small as that of the naked polynucleotide.

$<$ Chain exchange reaction (20) > When the s-SPG/polynucleotide complex meets the corresponding complementary
複合体形成を on-off で制御することが可能である。クリプタン ド [2, 2, 2] はカリウムイオンと強く錯形成することから、クリ プタンドを添加することで系中のフリーのカリウムイオン濃度 をコントロールすることができる。従って、クリプタンドと $\mathrm{KCl}$ を poly(U)/s-SPG 複合体溶液中へと添加すると図 4 に示す ように複合体形成を可逆的にスイッチングすることが可能であ る。

一方、 poly(C)、poly (A)、poly(dA)、poly(dT) はs-SPG と複 合体を形成する。これまでの研究によって (18)、複合体を形成 しない $\operatorname{poly}(\mathrm{G}) 、 \operatorname{poly}(\mathrm{dG}) 、 \operatorname{poly}(\mathrm{U}) 、 \operatorname{poly}(\mathrm{dC}) 、 \operatorname{poly}(\mathrm{I})$ は分子間 相互作用によって塩基中の水素結合サイトが占有されているこ とが示されている。一方、poly(C)、poly(A)、poly(dA)、poly(dT) の場合はそのような分子内相互作用を起こさず、水素結合サイ トが空いていることが示されている。これらの構造的特徵は複 合体形成と一致を示しており、核酸と s-SPG の相互作用誘起に 水素結合性相互作用が重要であることを示唆している。

\section{B-3. 核酸/SPG 複合体の性質}

<化学量論比 (16)> poly(A)、poly(dA) 及び poly(C) との 複合体形成における化学量論比を見積もった。その結果、二個 の主鎖グルコースと一個の核酸塩基が結合する、つまり、複合 体形成は二本の s-SPG と一本の核酸鎖による三本鎖形成である ことがわかった。

くヌクレアーゼ耐性 (19)＞複合体中に核酸が取り込まれ ることによってヌクレアーゼによる核酸加水分解に対して抵抗 性を示すようになる。ミカエリスーメンテン式から酵素反応を解 析した結果、反応速度は核酸のみの場合に比べて約六分の一程 度になっていることを確かめている。

<鎖交換反応 $(20)>$ 複合体中の核酸と相補的な配列を持 つ核酸が系中に存在する場合、例えば s-SPG/poly(dT) 複合体と 
sequence, for example, s-SPG/poly (dT) meets poly (dA), the complex dissociates immediately and hybridization takes place. In contrast, the complex was unaffected upon addition of noncomplementary strands.

\section{Application to a Novel DNA Carrier}

SPG has the potential to become a DNA carrier because of its nontoxic nature and the features of the complex as described above. Hereinafter, we report our recent results of evaluating the performance of SPG as an antisense oligonucleotide (AS ODN) or CpG DNA carrier.

\section{C-1. Chemical Modification of SPG}

SPG has no ability to bind to plasma membranes to induce endocytosis or other uptake processes. Therefore, we need to modify the SPG chain with a functional group which can induce uptake of DNAs. It is essentially important to introduce the functional groups only to the SPG side chain. This is because the $\beta-(1-3)$-D-glucan main chain is necessary to form the complex with polynucleotides or AS ODNs $(21,22)$, thus it is better to keep the main chain intact during the reaction. Fig. 5 (I) shows a reaction scheme $(23,24)$ in which we adopted peptides, or amine derivatives. The key step is oxidation of the side chain glucose by periodate anion $\left(\mathrm{IO}_{4}^{-}\right)$, which leads to cleavage of the pyranose ring and converts each end to the formyl terminate. When we attached amines, the formyl group of SPG reacted with the amino group (ii in the figure) and the subsequent reduction (iii) of the resultant Schiff base produced the final products. When we introduced the peptides to the side chain, we applied a conventional method using the addition of $\mathrm{N}$-terminal cysteine to the unsaturated bond in the maleimide moiety ( $v$ and vi in Fig. 5).

\section{C-2. Delivery of Antisense Oligonucleotide (AS ODN)}

The principles and mechanisms of antisense therapy are poly $(\mathrm{dA})$ があると、複合体はすぐに解離し、核酸二本鎖形成が 起こる。非相補的核酸が共存してもこのような鎖交換反応は起 こらない。

\section{DNA キャリヤーとしての応用}

SPG はその安全性と上述した複合体特性から DNA キャリ ヤーとして有望である。そこで我々はSPG のアンチセンスオリ ゴヌクレオチド (AS ODN) 及び CpG DNA キャリヤーへの応用 を図っている。

\section{C-1. SPG 化学修飾}

SPG には細胞膜に結合し、エンドサイトーシスやその他の 経路による取り込みを誘起する性質がない。そのため複合体の 取り込みを誘起するような機能性官能基を SPG 鎖に修飾する必 要がある。及-1,3-グルカン主鎖はポリヌクレオチドや AS ODN と の複合体形成に関与することから $(21 、 22)$ 、主鎖よりも側鎖への 化学修飾を行う方が複合体形成を阻害しないと考えられる。そ こで図 5 (i) に示すようなぺプチドやアミン誘導体を導入するた めの側鎖選択的化学修飾法を確立した $(23 、 24)$ 。まず、過ヨウ素 酸 $\left(\mathrm{IO}_{4}^{-}\right)$による側鎖グルコースの酸化反応によりピラノース環 を解裂させ、ホルミル基へと变換する。そして、アミンを側鎖 へ化学修飾する場合、SPG 側鎖のホルミル基とアミン誘導体の アミノ基を反応させることでシッフ塩基を形成させ (ii)、還元を 行う (iii)ことで側鎖アミン誘導体を得ることができる。ペプチ ドを側鎖へ修飾する場合には、側鎖へマレイミド基を導入した 後、ペプチド末端に導入したシステインのチオール基と反応さ せる $(\mathrm{v}$ 及び vi) ことで導入可能である。

C-2. アンチセンスオリゴヌクレオチド (AS ODN) デリバリー アンチセンス療法の原理とメカニズムは、(1) AS ODNを

I) Amine-appended SPG

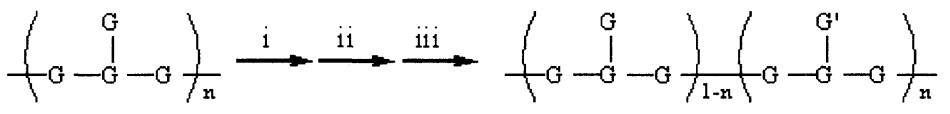

II) Peptide-appended SPG
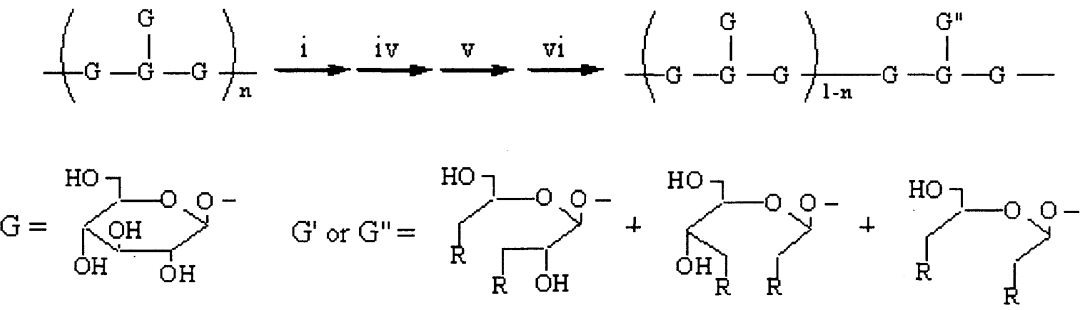

Reagents and conditions: (i) $\mathrm{NaIO}_{4}, \mathrm{H}_{2} \mathrm{O}, 4^{\circ} \mathrm{C}, 2$ days, (ii) amine or amino acid, DMSO, rt, 2 days, (iii) $\mathrm{NaBH}_{4}, \mathrm{DMSO}, \mathrm{rt}, 1$ day, (iv) $28 \% \mathrm{NH}_{3}$ aq., $\mathrm{NaBH}_{3} \mathrm{CN}, \mathrm{DMSO}, \mathrm{rt}, 4$ days, $N$-succinimi dyl-3-m aleimidopropionate, DMSO, rt, 1 day, (vi) peptide, DMSO, rt, 2 days

Fig. 5. Reaction scheme to introduce the functional groups into the side chain of s-SPG. 
(i) to deliver AS ODNs to cells, (ii) to induce cellular uptake of AS ODNs, (iii) to release AS ODNs to cytosol, (iv) to bind to a particular mRNA to make a DNA/RNA duplex, and (v) to make RNase $\mathrm{H}$ cleave the target mRNA so as to inhibit the protein expression (25-27).

We carried out an in vitro antisense assay combining melanoma cell lines and a phosphorothioate AS ODN/ unmodified SPG complex to depress c-myb mRNA. Here, c-myb is a proto-oncogene encoding a nuclear transcription factor, and its over-expression usually leads to cancer. 5'-GTGCCGGGGTCT TCGGGC (dA $)_{40}-3$ ' phosphorothioate was used as an antisensec-myb (AS-c-myb). To bind to s-SPG, poly $(\mathrm{dA})_{40}$ was attached at the 3' end of this sequence. We found that the AS ODN bound to the complex reduces cell growth more efficiently than that of naked AS ODN. There are two reasons for the enhanced efficiency. One is that the complex can prevent the bound AS ODN from binding to albumin or other serum proteins, with the result that more AS ODN can be ingested by cells. The other reason is that the bound AS ODN is protected against DNase-mediated hydrolysis (28). However, the uptake efficiency of unmodified SPG itself is not so high; therefore, we modified SPG side chain with a functional group that can induce passive cellular ingestion (29). We attached amines, amino acids, an arginine-glycine-aspartic acid tripeptide (RGD) which can bind to an integrin
細胞へ送達し、(2) 細胞内へ取り込ませる。(3) サイトゾル中へ の AS ODN の放出、(4) 標的となる mRNA と AS ODN による DNA/RNA二重鎖形成、(5) DNA と二本鎖を形成している RNA を特異的に切断する RNase Hにより標的 mRNA の分解が起こ り、タンパク質発現が阻害される (25-27)。

まず、未修飾 SPG と c-myb 遺伝子に対するホスホロチオ エートAS ODNを複合化させ、メラノーマ細胞を用いた in vitro アンチセンスアッセイを行った。c-mybは転写因子をコードする 癌原遺伝子であり、その過剩発現は癌を引き起こすことが知ら れている。そこでこの c-mybに対するホスホロチオエート型 AS ODN (AS-c-myb) を用いアッセイを行った。配列はSPG と複合 体を形成させるために 3 ’末端に poly $(\mathrm{dA})_{40}$ を付加した 5'GTGCCGGGGTCTTCGGGC (dA) 40 - ’を用いた。その結果、SPG と複合化させることにより、AS ODN だけの場合と比べてょり 効果的に癌細胞の増殖を抑制できることがわかった。これは複 合体を形成することで培地中に含まれるアルブミンなどの血清 タンパク質の AS ODN に対する非特異吸着や DNase による加 水分解を抑制したためだと考えられる (28)。

しかしながら、未修飾 SPG の細胞への取り込みはあまり高 くない。そこで細胞導入効率をあげるためにSPG 側鎖へ機能性 官能基を修飾した (29)。機能性官能基としてアミン、アミノ 酸、インテグリンレセプターに結合するアルギニン-グリシン-ア

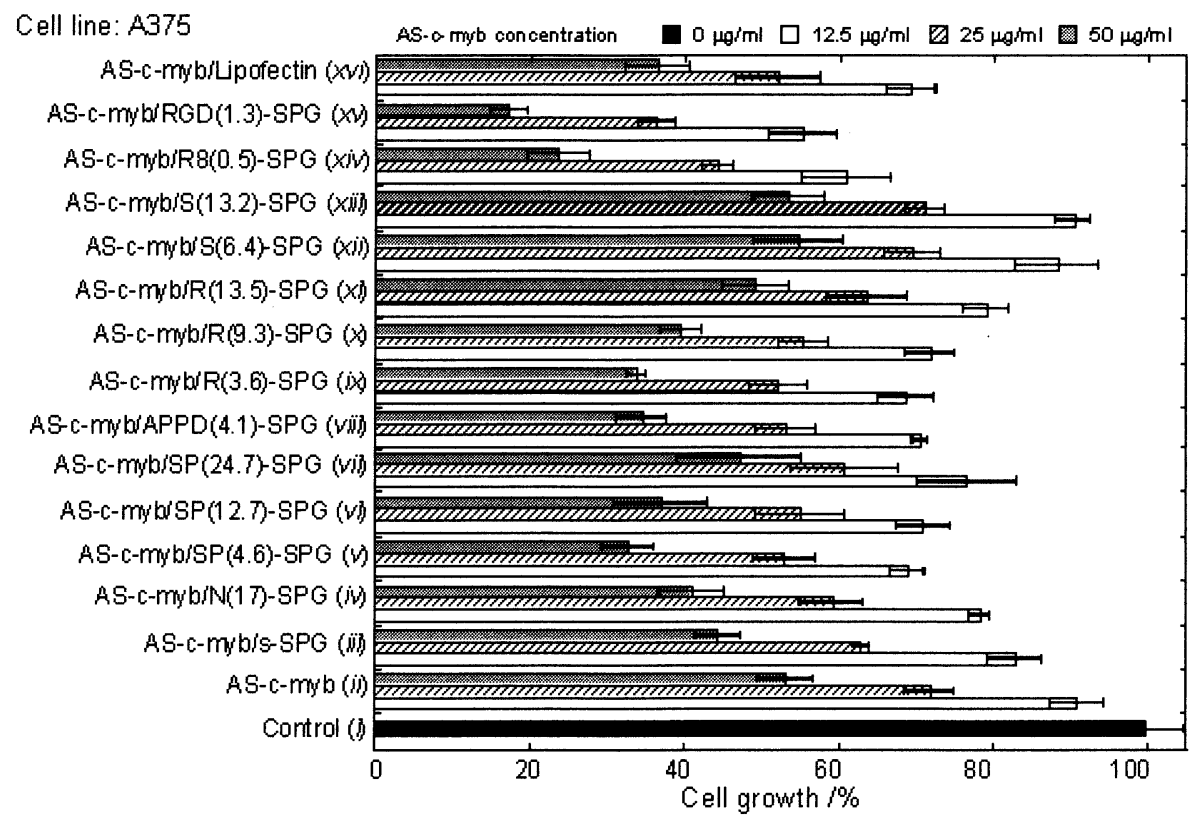

Fig. 6. Comparison of the cell growth, including the Lipofectin and unmodified s-SPG system, assayed for the A375 cell lines. The cell numbers were determined with Cell Counting Kit- $8^{\circledR}$ (Dojindo, Japan), after we administrated AS-cmyb with various carriers and incubated the cells for 3 days. The AS-c-myb doses were 12.5, 25, and $50 \mathrm{mg} / \mathrm{ml}$ (unfilled bar, hatched bar and filled bar, respectively). The cell growth is defined by the number of cells normalized by that of the control (without any addition of AS-c-myb nor s-SPG, (i)). The s-SPG/AS-c-myb molar ratio was fixed at 1:1. Abbreviation: N; 2 aminoethanol, SP; spermine, APPD; N,N'-bis(3-aminopropyl)-1,3-propanediamine, R; Arginine, S; Serine, R8; octa-arginine peptide, RGD; arginine-glycine-aspartic acid tripeptide, where the numbers in the parenthesis indicate the modification level of SPG side chain. 
receptor (30), and the arginine-rich peptide (R8) which induces a cellular uptake (31). Fig. 6 shows the A375 cell growth after culture for 3 days, comparing all combinations of AS-c-myb and every carrier, including Lipofectin and unmodified s-SPG system. As shown in Fig. 6, dramatic depression in the cell growth is observed when AS-c-myb was administrated as the RGD and R8 peptide attached s-SPG complex (xiv, xv). At 50 $\mathrm{mg} / \mathrm{ml}$ dose, the cell growths are depressed to $24 \%$ for R8(0.5)SPG and $17 \%$ for RGD(1.3)-SPG. The drastic depression can never be ascribed to the cytotoxicity of either phosphorothioates AS-c-myb or the peptide attached s-SPG. It should be emphasized that the very small amount of the modification level seems enough to enhance the cellular uptake efficiency. This work has thus clarified that SPG can act as a new potential candidate for AS ODN carriers.

\section{C-3. Delivery of CpG DNA (32)}

ODNs containing unmethylated $\mathrm{CpG}$ sequence $(\mathrm{CpG}$ DNA) have been shown to stimulate a cell-mediated immune response for mammals (33). This immune response is considered to be a defense system that mammals have evolved based on the fact that unmethylated $\mathrm{CpG}$ sequence emerges more frequently in bacterial DNA than in mammalian DNA. Considerable attention is devoted to this response because CpG DNA can be an extraordinarily effective adjuvant for many vaccines against infection agents, cancer antigens, and allergens. CpG DNA can be recognized by Toll-like receptor 9 (TLR-9) (34). Ahmad-Nejad et al.(35) demonstrated that TLR-9 is localized intracellularily, predicting that if we can efficiently deliver $\mathrm{CpG}$ DNA to endosome and/or lysosome, the immune response can be enhanced and controlled artificially.

We synthesized spermine (SP), RGD peptide, R8 peptide, and cholesterol (Chol) modified s-SPG according to the method illustrated in Fig. 5. The complexation was carried out between phosphorothioate CpG DNA 5'-TCCATGACGTTCCT GATG- $(\mathrm{dA})_{40}-3$ ' (the immunostimulatory sequence; PuPuCGPyPy is underlined) (36) and chemically modified sSPG. As shown in Fig. 7, when we exposed the murine macrophage-like cell J774.A1 to CpG DNA/chemically modified SPG complexes, dramatic enhancement in the cytokines (IL-6 (a), IL-12 (b), and TNF- $\alpha$ (c)) secretion was observed. The secretion increased 5-10 times from the naked dose and 100 times from the background. This performance promises that SPG can be an excellent carrier for CpG DNA.

\section{Conclusion}

This review reported the mechanism and properties of a novel polysaccharide/polynucleotide complex and showed potentiality to apply the complex to a functional ODN carrier. Although not presented here, we have extended application to a plasmid carrier $(37,38)$. Moreover, the complexation behavior of SPG is applicable to another field, such as analytical chemis-
スパラギン酸 (RGD) ペプチド (30)、細胞膜親和性を有するオリ ゴアルギニン (R8) ペプチド (31)を修飾した。図 6 にこれら化 学修飾 SPG と未修飾 SPG、市販導入試薬であるLipofectin を ASc-myb と複合化させ、A 375 細胞へ導入した三日後の細胞增殖率 を示す。図より、RGDやR8のペプチドを修飾したSPG と ASc-myb を用いることで大幅なアンチセンス効果の向上を示すこ とがわかった (xiv、xv)。 $50 \mathrm{mg} / \mathrm{ml}$ AS-c-myb を導入した場合、R8 (0.5)-SPG (カッコ内の数字は修飾率) で $24 \%$ 、RGD (1.3)-SPG で $17 \%$ まで細胞増殖を抑えた。このような大幅な抑制効果はホス ホロチオエート型 AS-c-myb やペプチド修飾 SPG の細胞毒性に よるものでないことを確認している。この実験により、側鎖へ のわずか数\%の化学修飾を行うことで細胞導入効率を向上させ ることがわかり、SPG は新規 AS ODN キャリヤーとして非常に 有用であることが確かめられた。

\section{C-3. CpG DNA デリバリー (32)}

メチル化されていない $\mathrm{CpG}$ 配列を有する ODN (CpG DNA) は哺乳動物の細胞性免疫を活性化することが報告されている (33)。哺乳類の DNA よりも細菌類の DNA にメチル化されてい ない $\mathrm{CpG}$ 配列が多く存在するということから、このような免疫 応答は外敵に対する防御機構であると考えられている。 $\mathrm{CpG}$ DNA は感染、癌、アレルギーなどに対する多くのワクチンの強 カなアジュバント(補助凰) として注目を集めている。CpG DNA は Toll-like receptor 9 (TLR-9) に認識されることが報告されてい る (34)。TLR-9 は細胞膜ではなく細胞内に局在する (35) ことか ら CpG DNA をエンドソーム/リソソーム経由で細胞内へ送達す ることができれば、免疫応答を増強し、人為的にコントロール することが可能である。

そこで我々はスペルミン (SP)、RGD ペプチド、R8 ペプチ ド、コレステロール (Chol) 修飾 SPG を図 5 に示した方法で合 成し、CpG DNA 細胞内導入を行った。CpG DNA はホスホロチ オエート型 5'-TCCATGACGTTCCTGATG-(dA) オ0 $^{-3}$ ' (下線は免疫 刺激配列; PuPuCGPyPy を示す) (36) を用い、これと化学修飾 SPG の複合化を行った。図 7 に示すように、マウスマクロファージ 様細胞 J774.A1 を用いた場合、化学修飾 SPG との複合化によっ て CpG DNA のみの場合と比べ 5 10 倍、無添加の場合よりも 100 倍もの大幅なサイトカイン (IL-6 (a)、IL-12 (b)、and TNF- $\alpha$ (c)) の分泌が観測された。以上の結果より SPG は CpG DNA キャリ ヤーとしても有用であることが確かめられた。

\section{D. まとめ}

本総説では新規な多糖/核酸複合体形成のメカニズムとその 性質について述べ、ODNキャリヤーとして応用可能であること を示した。ここでは述べることができなかったが、ODNキャリ ヤーとしての知見をもとに遺伝子(プラスミド)キャリヤーとし ての応用も図っている $(37 、 38)$ 。さらに SPG 複合体形成は分析 
try, and material science. For example, we have developed an mRNA separation system using SPG appended columns (39), and mRNA detection systems using fluorescence polarization (40), and Limulus G test (41). More recently, we found that SPG can entrap single walled carbon nanotubes (42). We believe that SPG can be one of the fundamental materials which support nanotechnology from a molecular level.
化学や材料科学など様々な分野への応用が可能である。例え ば、SPG 修飾カラムを用いた mRNA 分離システム (39)、蛍光 偏光解消 (40) やリムルス Gテスト (41) を利用した mRNA 検出 システムの開発である。また、最近、SPGが単層カーボンナノ チューブに巻き付くことも見出している (42)。以上より、SPG の性質を利用することで多岐の分野にわたる応用が可能であ り、さらなる展開が期待できる。

\section{References}

1. Verma, I. M., and Somia, N. (1997) Nat. Genet. 389, 239-242

2. Anderson, W. F. (1998) Nature 392, 25-30

3. Ledley, F. D. (1995) Hum. Gene Ther. 6, 1129-1144

4. DeLong, R., Stephenson, K., Loftus, T., Fisher, M., Alahari, S., Nolting, A., and Juliano, R. L. (1997) J. Pharm. Sci. 86, 762-764

5. Boussif, O., Lezoualch, F., Zanta, M. A., Mergny, M. D., Scherman, D., Demeneix, B., and Behr, J. P. (1995) Proc. Natl. Acad. Sci. U. S. A. 92, 7297-7301

6. Clarenc, J. P., Degols, G., Leonetti, J. P., Milhand, P., and Lebleu, B. (1993) Anticancer Drug Des. 8, 81-94

7. Chirila, T. V., Rakoczy, P. E., Garrett, K. L., Lou, X., and Constable, I. J. (2002) Biomaterials 23, 321-342

8. Caplen, N. J., Kinrade, E., Sorgi, F., Gao, X., Grunert, D., Geddes, D., Coutelle, C., Huang, L., Alton, E. W. F. W., and Williamson, R. (1995) Gene Ther. 2, 603-613

9. Wheeler, C. J., Felgner, P. L., Tsai, Y. J., Marshall, J., Sukhu, L., Doh, S. G., Hartikka, J., Nietupski, J., Manthorpe, M., Nichols, M., Plewe, M., Liang, X., Norman, J., Smith, A., and Cheng, S. H. (1996) Proc. Natl. Acad. Sci. U. S. A. 93, 11454-11459

10. Yanaki, K., Ito, W., Kojima, W., Norisuye, T., Takano, N., and Fujita, H. (1983) Biophys. Chem. 17, 337-342

11. Tabata, K., Ito, W., Kojima, T., Kawabata, S., and Misaki, A. (1981) Carbohydr. Res. 89, 121-135

12. Norisuye, T., Yanaki, T., and Fujita, H. (1980) J. Polym. Sci., Polym. Phys. Ed. 18, 547-558

13. Norisuye, T., and Yanaki, T. (1982) Polym. J. 15, 389-396

14. Sakurai, K., and Shinkai, S. (2000) J. Am. Chem. Soc. 122, 4520-4521

15. Mizu, M., Kimura, T., Koumoto, K., Sakurai, K., and Shinkai, S. (2001) Chem. Commun. 429-430

16. Sakurai, K., Mizu, M., and Shinkai, S. (2001) Biomacromolecules 2, 641-650

17. Sakurai, K., Iguchi, R., Koumoto, K., Kimura, T., Mizu, M., Hisaeda, Y., and Shinkai, S. (2002) Biopolymers 65, 1-9

18. Saenger, W. (1984) Principles of Nucleic Acid Structure, Springer-Verlag, New York, Chapter 13

19. Mizu, M., Koumoto, K., Kimura, T., Sakurai, K., and Shinkai, S. (2004) Biomaterials 25, 3109-3116

20. Koumoto, K., Mizu, M., Sakurai, K., Kunitake, T., and Shinkai, S. (2004) Chemistry \& Biodiversity 1, 520-529

21. Kimura, T., Koumoto, K., Sakurai, K., and Shinkai, S. (2000) Chem. Lett. 1242-1243

22. Koumoto, K., Kimura, T., Kobayashi, H., Sakurai, K., and Shinkai, S. (2001) Chem. Lett. 908-909

23. Koumoto, K., Kimura, T., Mizu, M., Sakurai, K., and Shinkai, S. (2001) Chem. Commun. 1962-1963

24. Numata, M., Matsumoto, T., Umeda, M., Koumoto, K., Sakurai, K., and Shinkai, S. (2003) Bioorganic Chem. 31, $163-171$

25. Uhlmann, E., and Peyman, A. (1990) Chem. Rev. 90, 543-584

26. Stein, C. A., and Cheng, Y. C. (1993) Science 261, 1004-1012

27. Stein, C. A., and Krieg, A. M. (1998) Applied Antisense Oligonucleotide Technology, Wiley-Liss, New York

28. Mizu, M., Koumoto, K., Anada, T., Karinaga, R., Kimura, T., Nagasaki, T., Shinkai, S., and Sakurai, K. (2004) Bull Chem. Soc. Jpn. 77, 11011110

29. Matsumoto, T., Numata, M., Anada, T., Mizu, M., Koumoto, K., Sakurai, K., Nagasaki, T., and Shinkai, S. (2004) Biochim. Biophys. Acta 1670, 91-104

30. Colin, M., Harbottle, R. P., Knight, A., Kornprobst, M., Cooper, R. G., Miller, A. D., Turgnan, G., Capeau, J., Coutelle, C., and Brahimi-Horn, M. C. (1998) Gene Ther. 5, 1488-1498

31. Suzuki, T., Futaki, S., Niwa, M., Tanaka, S., and Ueda, K. (2002) J. Biol. Chem. 277, 2437-2443

32. Mizu, M., Koumoto, K., Anada, T., Matsumoto, T., Numata, M., Shinkai, S., Nagasaki, T., and Sakurai, K. (2004) J. Am. Chem. Soc. 126, $8372-8373$

33. Krieg, A. M. (2003) Nat. Med. 9, 831-835

34. Henmi, H., Takeuchi, O., Kawai, T., Kaisho, T., Sato, S., Sanjo, H., Matsumoto, M., Hoshino, K., Wagner, H., Takeda, K., and Akira, S. (2000) Nature 408, 740-745

35. Ahmad-Nejad, P., Häcker, H., Rutz, M., Bauer, S., Vabulas, R. M., and Wagner, H. (2002) Eur. J. Immunol. 32, 1958-1968

36. Aramaki, Y., Yotsumoto, S., Watanabe, H., and Tsuchiya, S. (2002) Biol, Pharm. Bull. 25, 351-355

37. Nagasaki, T., Hoji, M., Uno, T., Satoh, K, Koumoto, K., Mizu, M., Sakurai, K., and Shinkai, S. (2004) Bioconjugate Chem. 15, 249-259

38. Anada, T., Matsunaga, H., Karinaga, R., Koumoto, K., Mizu, M., Nakano, K., Shinkai, S., and Sakurai, K. (2004) Bioorg. Med. Chem. Lett. 14, 5655-5659

39. Kimura, T., Koumoto, K., Mizu, M., Sakurai, K., and Shinkai, S. (2002) Chem. Lett. 1240-1241

40. Karinaga, R., Mizu, M., Koumoto, K., Anada, T., Shinkai, S., and Sakurai, K. (2004) Chemistry \& Biodiversity, 1, $634-639$

41. Anada, T., Koumoto, K., Mizu, M., Karinaga, R., Sakurai, K., and Shinkai, S. (2003) Anal. Sci. 19, 1567-1568

42. Numata, M., Asai, M., Kaneko, K., Hasegawa, T., Fujita, N., Kitada, Y., Sakurai, K., and Shinkai, S. (2004) Chem. Lett. 33, 232-233 


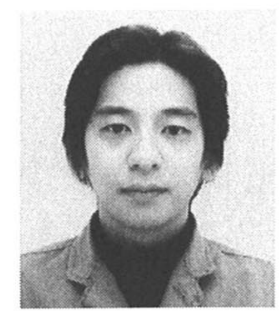

Takahisa Anada has been a post doctoral fellow in the SORST Project (Japan Science and Technology Corporation (JST)), and working in Kazuo Sakurai's laboratory in The University of Kitakyushu from April, 2003. He graduated from the Faculty of Engineering of Kyushu University, and received his Ph.D. in 2003. His main research interests are development of gene carriers using polysaccharides.

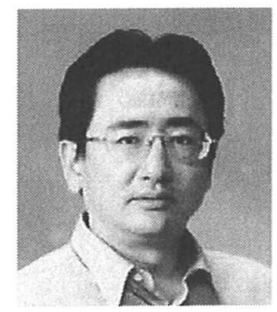

Kazuo Sakurai is a professor of the Dept. of Chemical Processes and Environments, Faculty of Environmental Engineering, The University of Kitakyushu. After finishing the master course of the Dept. of Macromolecular Science, Osaka University, he worked at the central research center of Kanebo Ltd until 1999, involved in application to conductive polymers to batteries, DDS, a new polyester resin containing fluorene. He spent three years at Prof. MacKinght's Lab in Umass, Amherst in USA from 1990-93. During that time, he learned SAXS and polymer blends. He received his Ph.D. from the Graduate School of Macromolecular Science, Osaka University in 1996. After the collapse of the Kanebo research center, he joined Prof. Shinkai's project (ICORP, JST) and moved to his present position in 2002. His major research interest covers topics from small-angle X-ray scattering form soft materials, polymer blends, polysaccharides, DNA DDS, to active carbons.

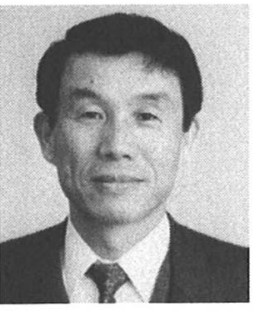

Seiji Shinkai was born in 1944 in Fukuoka, Japan, and received his Ph.D. in 1972 from Kyushu University, where he became a lecturer soon afterwards. After postdoctoral work at the University of California, Santa Barbara with Thomas C. Bruice, he joined Kyushu University in 1975 and became a full professor there in 1988. He has launched a SORST Project (Japan Science and Technology Corporation (JST)) related to sugar-based gene manipulators from March 2002. His research interests focus on host-guest chemistry, molecular recognition, sugar sensing, allosteric functions, organogels, sol-gel transcription, polysaccharide-polynucleotide interactions, etc. 